\title{
Toxicity of thiametoxam on in vitro reared honey bee brood
}

\author{
Giacomo Grillone, Daniela Laurino, Aulo Manino, Marco Porporato \\ Dipartimento di Scienze Agrarie, Forestali e Alimentari, Università di Torino, Largo Paolo Braccini 2, Grugliasco, 10095, \\ Turin, Italy
}

Received 22 November 2016 - Revised 22 February 2017 - Accepted 14 March 2017

\begin{abstract}
Pesticides are a possible cause of pollinator decline and honey bee colony losses experienced in several countries in recent years. In the past years, many north-west Italian beekeepers reported the presence of dead brood in field apiaries during neonicotinoid-coated maize sowing; therefore, a possible role of these insecticides was suspected. The objective of this study was to test this hypothesis. Laboratory repeated dose toxicity tests on in vitro reared larvae were carried out using thiamethoxam. The repeated treatment median lethal concentration $\left(\mathrm{LC}_{50}\right)$ and the median lethal dose $\left(\mathrm{LD}_{50}\right) 14$ and 19 days after grafting were calculated and resulted of the same order of magnitude of realistic brood exposure under a worst-case scenario. Various sublethal effects, like brownish larvae, duplication of the pupal integument, delay in development, and deformed adults were also observed.
\end{abstract}

\section{Apis mellifera / artificial rearing / cumulative toxicity / neonicotinoids / sublethal doses / thiametoxam}

\section{INTRODUCTION}

An extensive pollinator decline (Gallai et al., 2009; Potts et al., 2010; Nieto et al., 2014) and heavy honey bee colony losses (Janke and Rosenkranz, 2009; Neumann and Carreck, 2010) have been experienced in several countries lately. In the effort to bring light on the origin of these phenomena, several factors have so far been investigated. Furthermore, new features like the colony collapse disorder (CCD) syndrome have been described (vanEngelsdorp et al., 2009), nevertheless not a single cause was definitively identified (Maini et al., 2010; Ratnieks and Carreck, 2010; Williams et al., 2010). Therefore, it is most likely that some multifactorial effect is involved, and lately, the cumulative action of several stressors on the honey bee's immune response has been proposed as a unifying model (Nazzi et al., 2012; Di Prisco et al., 2013).

Corresponding author: D. Laurino,

daniela.laurino@unito.it

Manuscript Editor: Monique Gauthier
Among the various factors suggested, pesticides are one of the most relevant and in-depth investigated causes of colony losses (Blacquière et al., 2012; Krupke et al., 2012; Lu et al., 2012; van der Sluijs et al., 2013; European Academies Science Advisory Council, 2015). In particular, neonicotinoid insecticides - especially when used in seed coating-were greatly debated since heavy honey bee mortalities were observed in Italy and other European countries during maize sowing (Greatti et al., 2003 and 2006; Forster, 2009; Pistorius et al., 2009; Chauzat et al., 2010; van der Geest, 2012). At last, these facts led in 2008 to the ban of the use of neonicotinoids and fipronil as coating active ingredients for maize and sunflower. As a result, a dramatic reduction in the poisoning incidents reported in Italy was observed (APENET, 2009). In the years before the ban, many north-west Italian beekeepers reported dead brood with symptoms reminding the European foul brood (EFB) in their hives during maize sowing, but an EFB diagnosis was not confirmed. After the neonicotinoid and fipronil use had been restricted, this syndrome nearly disappeared; therefore, a possible role of these insecticides in 
causing such symptoms was suspected, and the objective of this study is to test this hypothesis.

Pesticide risk assessment on honey bee brood is far more complex than on adult workers, especially when chronic or sublethal effects are involved, since the honey bee brood develops in the hives and carefully reared inside comb cells, and exposure to pesticides is mostly mediated by both forager and nurse adult workers. Due to such difficulties, several laboratory (Czoppelt 1991; Davis et al., 1988; Mussen et al., 2004; Aupinel et al., 2007a, b; Gregorc and Ellis, 2011; Hendriksma et al., 2011; Tavares et al., 2015), cage (Schur et al., 2003), and field procedures (Oomen et al., 1992; Everich et al., 2009) have been proposed for testing pesticide toxicity on honey bee brood and to assess experimental results. Presently, a universal consensus on a specific methodology for testing pesticides on honey bee brood has not yet been achieved (Aupinel et al., 2009; European Food Safety Authority, 2013a, b). Nonetheless, as a first step to detect any possible relationship between neonicotinoids and honey bee brood anomalies, we planned some laboratory toxicity tests on in vitro reared larvae hoping that the results could contribute to the debate. A repeated dose exposure test modified from Aupinel's test (Aupinel et al., 2007a, b) was developed, and thiamethoxam was used as toxic agent, since it is extensively used on crops and its toxicity to honey bees is well known even though the few available data on larvae are controversial (European Food Safety Authority, 2013a).

\section{MATERIALS AND METHODS}

\subsection{Brood rearing}

First instar worker larvae were collected from three A. m. ligustica colonies. Computer-assisted wing venation morphometric analysis (Meixner et al., 2013) was used to assess the honey bee subspecies. The hives were periodically checked to exclude the presence of the most common honey bee diseases (Shimanuki and Knox, 2000).

The larvae were grafted from a single brood comb into the wells of a sterile 48-well tissue culture plate; different plates were used for each tested colony. After grafting, the brood was reared in a dark incubator at $34.5( \pm 0.5){ }^{\circ} \mathrm{C}$ for 21 days to allow adult emergence. Larvae were kept at $96 \%$ relative humidity in hermetic desiccators containing dishes filled with a $\mathrm{K}_{2} \mathrm{SO}_{4}$ saturated solution, and pupae were kept at $80 \%$ relative humidity in hermetic desiccators containing dishes filled with a $\mathrm{NaCl}$ saturated solution.

The Aupinel's (Aupinel et al., 2005) semiartificial diet was adopted. Larvae were fed daily for 6 days putting a food drop onto the well's bottom; diet composition and amounts fed to larvae are shown in Table I. Fresh royal jelly produced in DISAFA's apiary, yeast extract from Biokar diagnostics (Beauvais, France), and sugars from Serva Feinbiobiochemica (Heiderberg, Germany) were used.

\subsection{Toxicity tests}

A thiamethoxam commercial formulation available in Italy (Actara ${ }^{\circledR} 25.0 \%$ pure thiamethoxam, hydro-dispersible granules) was used. It was mixed with the larval food so that known amounts of thiamethoxam were ingested by the larvae. Since the larvae were in contact with the artificial food, some contact action could not be completely excluded.

Preliminary tests were carried out to determine the concentration range between $100 \%$ mortality and a mortality level not significantly different from that of the untreated controls. On this basis, the following thiamethoxam concentrations were used to determine the $\mathrm{LC}_{50}: 20,10,5,2,1,0.5$, and $0.2 \mathrm{mg} / \mathrm{L}$. Three replications - one 48-well tissue plate per replicate-were done for each tested concentration and the untreated control, taking care that larvae from a different colony were used for each replicate.

From day 1 to day 5-day 0 being the day the larvae were grafted $-1 \mu \mathrm{L}$ of a thiamethoxam suspension in water was added to the food in each well with the treated larvae, and $1 \mu \mathrm{L}$ of water was added in the wells with the untreated control larvae. The thiamethoxam suspension concentrations were such as to obtain the desired test concentration after dispersion of the given $1 \mu \mathrm{L}$ drop in the larval food. Doses fed to larvae are shown in Table I. 
Table I.. Daily food volumes provided to the larvae, composition of the diet according to their age, and doses of thiamethoxam fed to larvae for each tested concentration from day 1 to day 5 after grafting, day 0 being the grafting day.

\begin{tabular}{llllllll}
\hline Rearing day & Day 0 & Day 1 & Day 2 & Day 3 & Day 4 & Day 5 & Total \\
\hline $\begin{array}{l}\text { Larval food amount }(\mu \mathrm{L}) \\
\text { diet composition }\end{array}$ & 10 & 10 & 20 & 30 & 40 & 50 & 160 \\
$\quad$ Royal jelly (\%) & 50 & 50 & 50 & 50 & 50 & 50 & - \\
Yeast extract (\%) & 1 & 1 & 1.5 & 2 & 2 & 2 & - \\
D-glucose (\%) & 6 & 6 & 7.5 & 9 & 9 & 9 & - \\
D-fructose (\%) & 6 & 6 & 7.5 & 9 & 9 & 9 & - \\
Dry matter (\%) & 29.55 & 29.55 & 33.05 & 36.55 & 36.55 & 36.55 & - \\
Thiamethoxam dose (ng/larva) & & & & & & & \\
$20 \mathrm{mg} / \mathrm{L}$ & - & 200 & 400 & 600 & 800 & 1000 & 3000 \\
$10 \mathrm{mg} / \mathrm{L}$ & - & 100 & 200 & 300 & 400 & 500 & 1500 \\
$5 \mathrm{mg} / \mathrm{L}$ & - & 50 & 100 & 150 & 200 & 250 & 750 \\
$2 \mathrm{mg} / \mathrm{L}$ & - & 20 & 40 & 60 & 80 & 100 & 300 \\
$1 \mathrm{mg} / \mathrm{L}$ & - & 10 & 20 & 30 & 40 & 50 & 150 \\
$0.5 \mathrm{mg} / \mathrm{L}$ & - & 5 & 10 & 15 & 20 & 25 & 75 \\
$0.2 \mathrm{mg} / \mathrm{L}$ & - & 2 & 4 & 6 & 8 & 10 & 30 \\
\hline
\end{tabular}

${ }^{a}$ Calculated from Crane (1990) for royal jelly and manufacturer's specifications for the remaining ingredients

Mortality and any morphological and/or developmental anomaly that could be considered as a sublethal effect were visually checked and recorded daily immediately before feeding. Larvae that died within $24 \mathrm{~h}$ after grafting were removed from the experiments and all computations in order to exclude grafting effects.

Two toxicity endpoints were evaluated: (i) cumulative mortality at day 14 after grafting as an assessment of living pupae (individual not molted from prepupa to pupa on day 14 after grafting were considered as dead in the pre-pupal phase); (ii) number of emerged adults (non-emerged individuals on day 21 after grafting were counted as dead during the pupal stage).

\subsection{Statistical analysis}

The larval survival was analyzed with the survival analysis module of the statistical package PAST 3.05 (Hammer et al., 2001). The KaplanMeier survival curves for the tested concentration and the untreated control were drawn, and each concentration curve was compared with that of the untreated control by means of the log-rank test.
The Kaplan-Meier curves and the log-rank tests were computed according to Kleinbaum and Klein (2005). The obtained $P$ values were corrected with the Holm-Bonferroni procedure (Holm, 1979) to provide a multicomparison correction.

The median lethal concentration $\left(\mathrm{LC}_{50}\right)$ at day 14 and day 19 after grafting and the relative $95 \%$ confidence intervals were calculated by means of probit analysis; the procedure devised by Milani (1995) was adopted. Since in the tests each honey bee larva ingests a total of $150 \mu \mathrm{L}$ of food from day 1 to day 5 (Table I), the repeated treatment cumulative median lethal dose $\left(\mathrm{LD}_{50}\right)$ was obtained from the relative $\mathrm{LC}_{50}$. Moreover, the $\mathrm{LC}_{50}$ at day 14 and day 19 after grafting were calculated from mortality data relative to each tested colony; subsequently, the three pairwise $\mathrm{LC}_{50}$ ratios were calculated and their statistical significance determined, under the null hypothesis that they are identical, following the procedure given by Robertson and Preisler (1992) and the computational details adopted by Laurino et al. (2013).

The frequency of individuals showing sublethal effects below $\mathrm{LC}_{50}$ concentrations were 


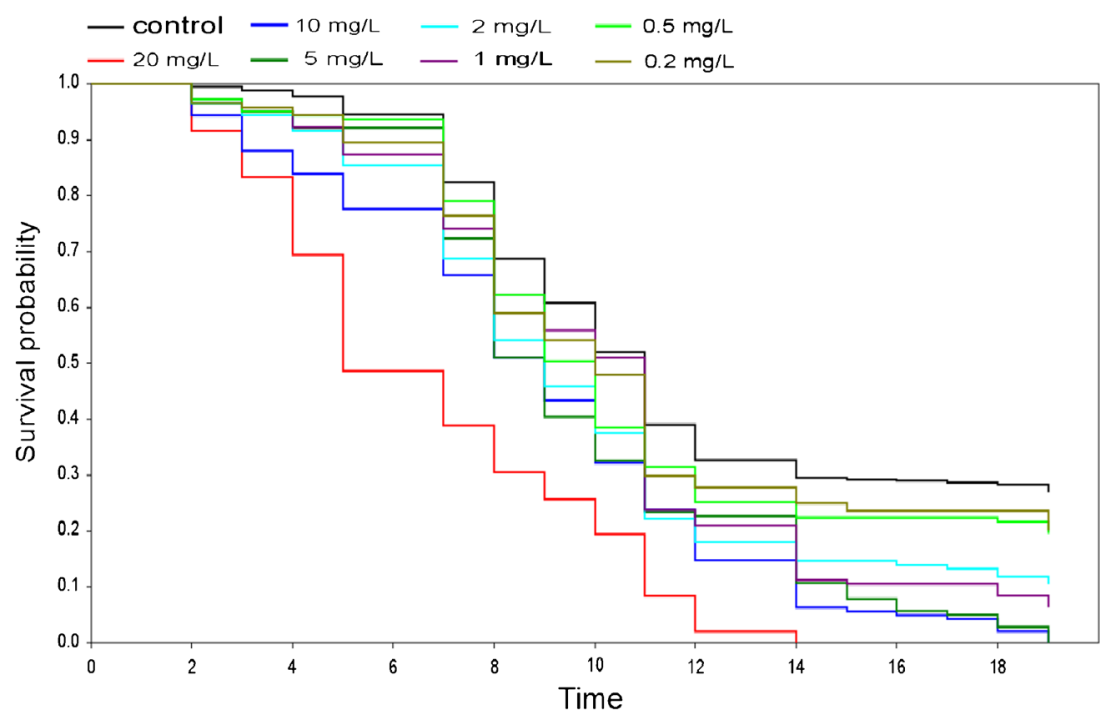

Figure 1. Kaplan-Meier survival dynamic curves of honey bee worker brood treated with decreasing thiamethoxam concentrations and of the untreated controls.

compared with those observed in the untreated controls by means of Pearson's $\chi^{2}$ test of independence with d.f. $=1$ and significance $P$ values were calculated with a Monte Carlo permutation test with 9999 replicates. The statistical package PAST 3.05 (Hammer et al., 2001) was used for these computations.

\section{RESULTS}

Larval mortality $24 \mathrm{~h}$ after grafting was always very low (0-3 dead larvae/plate; average survival \pm standard deviation $=99.2 \pm 1.64 \%$ ). In the following days, mortality increased throughout the experiments, although feeding and, therefore, thiamethoxam administration had ceased 5 days after grafting to allow fully grown larvae to transform into prepupae.

Kaplan-Meier survival dynamic curves show a regular increase in mortality from the untreated controls to the highest tested thiamethoxam concentration (Figure 1). All tested concentrations resulted statistically highly different from those of the untreated controls $(P<0.01)$ except for the lowest one $(0.2 \mathrm{mg} / \mathrm{L})$ which was hardly significant $(P<0.05)$ as a consequence of the HolmBonferroni correction (Table II).

Table II.. Survival dynamics of in vitro reared honey bee worker brood treated with decreasing thiamethoxam concentrations compared with those of the untreated controls.

\begin{tabular}{lclll}
\hline Thiamethoxam concentration comparisons & Log-rank $\chi^{2}$ & Bonferroni-Holm corrected $\alpha$ & $P$ (same) value \\
\hline $20 \mathrm{mg} / \mathrm{L}$ vs control & 164.91 & 0.05 & 0.01 & $9.57 \times 10^{-38 * *}$ \\
$10 \mathrm{mg} / \mathrm{L}$ vs control & 79.45 & 0.025 & 0.005 & $4.96 \times 10^{-19 * *}$ \\
$5 \mathrm{mg} / \mathrm{L}$ vs control & 120.28 & 0.0166 & 0.00333 & $5.49 \times 10^{-28 * *}$ \\
$2 \mathrm{mg} / \mathrm{L}$ vs control & 64.45 & 0.0125 & 0.0025 & $9.92 \times 10^{-16 * *}$ \\
$1 \mathrm{mg} / \mathrm{L}$ vs control & 43.23 & 0.01 & 0.002 & $4.86 \times 10^{-11} * *$ \\
$0.5 \mathrm{mg} / \mathrm{L}$ vs control & 11.60 & 0.0083 & 0.00166 & $0.00066^{* *}$ \\
$0.2 \mathrm{mg} / \mathrm{L}$ vs control & 8.35 & 0.0072 & 0.00142 & $0.0039^{*}$ \\
\hline
\end{tabular}

Significant at $* P=0.05$; highly significant at $* * P=0.01$ 
Table III.. Thiametoxam repeated treatment median lethal concentration $\left(\mathrm{LC}_{50}\right)$ and median lethal dose $\left(L_{50}\right)$ for in vitro reared honey bee worker brood at day 14 and day 19 after grafting. In brackets $\mathrm{LC}_{50}$ and $\mathrm{LD}_{50}$ upper and lower limits at $P=0.95$

\begin{tabular}{lll}
\hline & Day 14 & Day 19 \\
\hline $\mathrm{LC}_{50}(\mathrm{mg} / \mathrm{L})$ & $1.53(0.33-3.26)$ & $0.79(0.25-1.39)$ \\
$\mathrm{LD}_{50}(\mathrm{ng} / \mathrm{larva})$ & $229(50-489)$ & $118(37-209)$ \\
\hline
\end{tabular}

$\mathrm{LC}_{50} 14$ days after grafting, when pupation was achieved by all surviving individuals, resulted in $1.53 \mathrm{mg} / \mathrm{L}$ of larval food, nearly the double of the value of $0.79 \mathrm{mg} / \mathrm{L}$ of larval food reached 5 days later after adult emergence (Table III). Food intake was substantially completed by all larvae reaching the prepupal phase, and therefore, an individual intake of $150 \mu \mathrm{L}$ of food was assumed to compute the $\mathrm{LD}_{50}$ values shown in Table III even if the larvae that died in the first days did not evidently ingest so much food. The three $\mathrm{LD}_{50}$ values calculated for each colony used in the tests were substantially similar, and no statistically significant difference emerged from the pairwise $\mathrm{LC}_{50}$ ratios.

Various anomalies and sublethal effects were observed in the reared brood (Figure 2). In general, sublethal effects were most abundant at lower concentrations than at higher ones, as far as the number of dead larvae and pupae diminished. They were categorised as shown in Table IV. normal brood
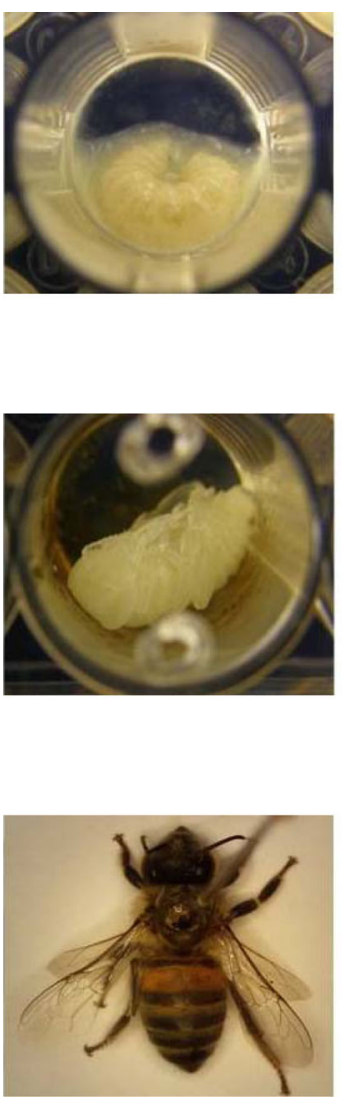

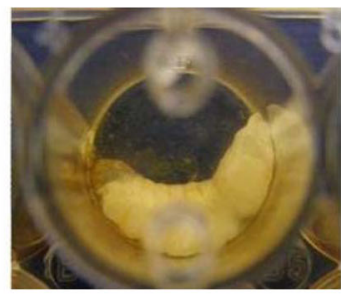

Pupal integument

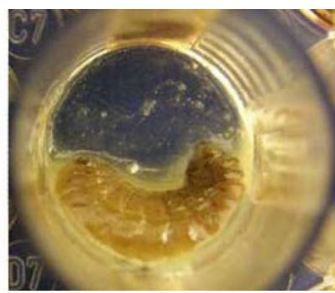

Colour of larvae

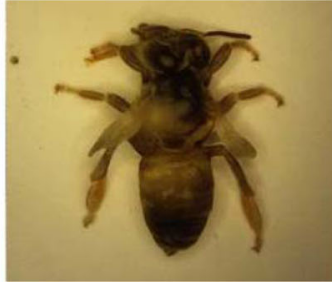

Adults abnormal brood
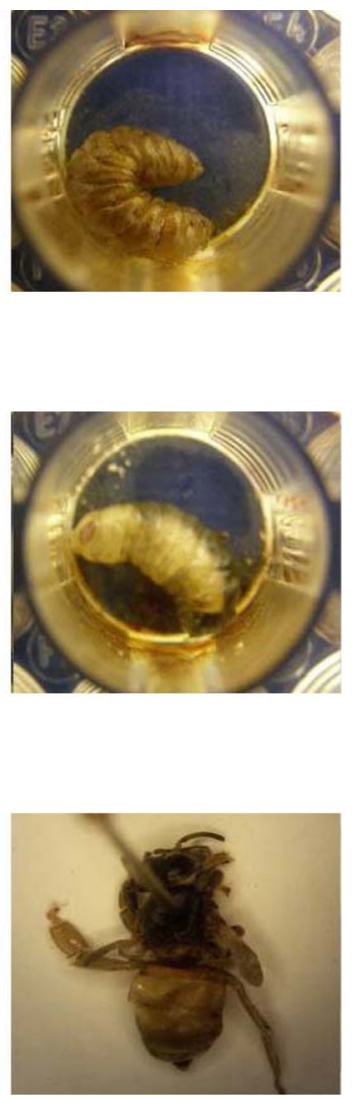

Figure 2. Sublethal effects observed in honey bee brood rearing tests. 
Table IV.. Number of sublethal effects showed by in vitro reared honey bee worker brood treated below $\mathrm{LC}_{50}$ thiamethoxam concentrations $(0.5$ and $0.2 \mathrm{mg} / \mathrm{L})$ and in the untreated controls. A number of normal individuals are reported for comparison purposes

\begin{tabular}{|c|c|c|c|c|}
\hline \multirow[t]{2}{*}{ Sublethal effect } & \multicolumn{2}{|l|}{ Larvae } & \multirow[t]{2}{*}{$\chi^{2}$} & \multirow[t]{2}{*}{ Monte Carlo $P$} \\
\hline & Treated & Control & & \\
\hline \multicolumn{5}{|l|}{ Color of larvae } \\
\hline Brownish & 141 & 114 & \multirow[t]{2}{*}{4.98} & \multirow[t]{2}{*}{$0.0281 *$} \\
\hline Pearly-white & 146 & 172 & & \\
\hline \multicolumn{5}{|l|}{ Pupation time } \\
\hline Delayed & 40 & 27 & \multirow[t]{2}{*}{10.11} & \multirow[t]{2}{*}{$0.0017 * *$} \\
\hline Normal & 26 & 52 & & \\
\hline \multicolumn{5}{|l|}{ Pupal integument } \\
\hline Double & 3 & 0 & \multirow[t]{2}{*}{3.42} & \multirow[t]{2}{*}{0.1091 n.s.*** } \\
\hline Normal & 66 & 77 & & \\
\hline \multicolumn{5}{|l|}{ Adult workers } \\
\hline Deformed & 36 & 62 & \multirow[t]{2}{*}{8.18} & \multirow[t]{2}{*}{$0.0073 * *$} \\
\hline Normal & 21 & 11 & & \\
\hline
\end{tabular}

*Significant $(P<0.01)$; **highly significant $(P<0.01)$; ***n.s. not significant at $p=0.05$

The number of brownish worker larvae treated with thiamethoxam concentrations below $\mathrm{LC}_{50}$ was significantly higher than that of untreated controls; pupation time was highly significantly delayed in treated brood, and significantly more deformed adults emerged from it in comparison with untreated controls. Moreover, three pupae still enclosed in the larval integument were also observed in the treated brood.

\section{DISCUSSION}

The very low larval mortality observed $24 \mathrm{~h}$ after grafting indicates that grafting effects were negligible throughout the experiment; thanks to the implementation of sound beekeeping practices in the management of the colonies the larvae were taken from and the correct grafting technique.

Feeding the larvae for 5 days with a constant thiamethoxam concentration instead of feeding them with a single dose in an early development stage, as suggested in most recently proposed protocols for testing pesticides on brood (Aupinel et al., 2007a, b; Hendriksma et al., 2011), seems a more realistic simulation of what may happen in a honey bee colony growing in an intensive farming area. The adopted repeated dose approach could anyhow be considered more as a chronic toxicity test than as an acute toxicity test; therefore, the use of Kaplan-Meier survival dynamic curves to depict the mortality increase, and of log-rank tests to compare them, appear fully justified. Since the untreated control mortality was higher than the optimal levels suggested in the literature (Aupinel et al., 2005 and 2009), the more restrictive value of $\alpha=0.01$ was preferred to the usual $\alpha=0.05$ to evidence statistical significance. Under such conditions, the lowest tested concentration could be regarded as the NOAEC for thiamethoxam on brood in the adopted experimental conditions.

$\mathrm{LC}_{50}$ figures obtained by us are of an order of magnitude lower than those reported by Tavares et al. (2015) for Africanized honey bees. Different responses to toxic compounds have been evidenced between honey bee strains (Ladas, 1972; Mansour and Al-Jalil, 1985; Suchail et al., 2000 Laurino et al., 2013), but in this case, the adopted experimental designs - single dose vs repeated doses - should account for the difference.

The use of $\mathrm{LC}_{50}$ - and/or the derived $\mathrm{LD}_{50}$-values to express the results of a repeated dose toxicity test could be somehow questionable, since they are more often derived from acute 
toxicity tests. In any case, they prove to be rather useful when comparing laboratory results with a realistic landscape-level exposure to pesticides. Honey bee larvae are exposed to pesticides chiefly through the food nurse bees give them since the amounts of pollen and honey given to them is very low. Nurse bees may eat contaminated pollen and nectar and thus produce larval food containing pesticides (Rortais et al., 2005). Therefore, effective exposure levels are difficult to determine. To overcome these difficulties, the EFSA guidance document on the risk assessment of plant protection products on bees (European Food Safety Authority, 2013b) proposes various shortcut values (SV) to be used for the estimation of oral exposure via nectar and pollen consumption under different scenarios. Since the reported EFB-like symptoms had been observed in field apiaries during maize sowing, the SVs proposed by EFSA for the adjacent crop $(4.4 \mu \mathrm{g} /$ larva $)$ and/or field margin $(2.2 \mu \mathrm{g} /$ larva $)$ scenarios can be considered as the most appropriate and should be chosen among the various SVs relative to honey bee larvae. These SVs refer to an a.i. application rate of $100 \mathrm{mg} / \mathrm{m}^{2}$, while the maximum application rate allowed for maize seed dressing in Italy was $6.3 \mathrm{mg} / \mathrm{m}^{2}$ only (European Food Safety Authority, 2013a); therefore, the SVs should be reduced to 272 and $136 \mathrm{ng} /$ larva respectively. In any case, it should be noted that such SVs are to be considered as a worst-case scenario. Since the $\mathrm{LD}_{50}$ values obtained in the present study are lower than the suggested SVs, it is likely that a widespread use of dressed seeds could expose honey bee larvae to dangerous thiamethoxam concentrations. Therefore, extensive brood mortality and colony weakening would likely occur.

Various sublethal effects of pesticides on honey bee brood have been reported in the literature (Desneux et al., 2007; Wu et al., 2011; Blacquière et al., 2012; Simon-Delso et al., 2014), and some of them, like the delay in pupation and in adult emergence, were observed also during this research. On the contrary, developmental troubles leading to the emergence of deformed adults and the extremely rare-and therefore not statistically significant - appearance of pupae that are still enclosed in the larval integument were not commonly observed and seem to be rather unlikely for neurotoxic insecticides like thiamethoxam.

\section{ACKNOWLEDGEMENTS}

The authors wish to thank Dr. Noa Simon-Delso for her helpful criticism on the earlier draft of the manuscript.

Toxicité du thiamétoxame sur le couvain d'abeille élevé in vitro

Apis mellifera / élevage artificiel / toxicité cumulative / néonicotinoïde / dose sublétale

Toxizität von Thiametoxam für in vitro aufgezogene Brut der Honigbiene

Apis mellifera / künstliche Aufzucht / kumulative Toxizität / Neonikotinoide / sublethale Dosis / Thiametoxam

\section{REFERENCES}

APENET (2009) Effects of coated maize seed on honey bees. Report based on results obtained from the first year of activity of the APENET project [on line] http://www.cra-api.it/online/immagini/Apenet_2009 eng.pdf (accessed on 28 April 2015)

Aupinel, P., Fortini, D., Dufour, H., Tasei, J., Michaud, B., Odoux, F., Pham-Delegue, M. (2005) Improvement of artificial feeding in a standard in vitro method for rearing Apis mellifera larvae. Bull. Insectol. 58, 107-111

Aupinel, P., Fortini, D., Dufour, H., Michaud, B., Marolleau, F., Tasei, J.N., Odoux, J.F. (2007a) Toxicity of dimethoate and fenoxycarb to honey bee brood (Apis mellifera), using a new in vitro standardized feeding method. Pest Manag. Sci. 63, 1090-1094

Aupinel, P., Medrzycki, P., Fortini, D., Dufour, H., Michaud, B., Tasei, J.N., Odoux, J.F. (2007b) A new larval in vitro rearing method to test effects of pesticides on honey bee brood. Redia 90, 91-94

Aupinel, P., Fortini, D., Michaud, B., Medrzycki, P., Padovani, E. et al. (2009) Honey bee brood ring-test: method for testing pesticide toxicity on honeybee brood in laboratory conditions. Julius-Kühn-Archiv 423, 96-102

Blacquière, T., Smagghe, G., van Gestel, C.A.M., Mommaerts, V. (2012) Neonicotinoids in bees: a review on concentrations, side-effects and risk assessment. Ecotoxicology 21, 973-992 
Crane, E. (1990) Bees and beekeeping: science, practice and world resources. Heinemann Newnes, Oxford

Chauzat, M.-P., Martel, A.-C., Blanchard, P., Clément, M.C., Schurr, F., Lair, C., Ribière, M., Wallner, K., Rosenkranz, P., Faucon J.-P. (2010) A case report of a honey bee colony poisoning incident in France. J. Apic Res. 49, 113-115

Czoppelt, C. (1991) Evaluation of toxicity of the juvenoid phenoxycarb to honeybee larvae reared in vitro. Apidologie 22, 457-459

Davis, A.R., Solomon, K.R., Shuel, R.W. (1988) Laboratory studies of honeybee larval growth and development as affected by systemic insecticides at adultsublethal levels. J. Apic. Res. 27, 146-161

Desneux, N., Decourtye, A., Delpuech J.-M. (2007) The Sublethal Effects of Pesticides on Beneficial arthropods. Annu. Rev. Entomol. 52, 81-106

Di Prisco, G.D., Cavaliere, V., Annoscia, D., Varricchio, P., Caprio, E., Nazzi, F., Gargiulo, G., Pennacchio, F. (2013) Neonicotinoid clothianidin adversely affects insect immunity and promotes replication of a viral pathogen in honey bees. PNAS 110 (46), 18466-18471

European Academies Science Advisory Council (2015) Ecosystem services, agriculture and neonicotinoids. German National Academy of Sciences Leopoldina, Halle (Saale)

European Food Safety Authority (2013a) Conclusion on the peer review of the pesticide risk assessment for bees for the active substance thiamethoxam. EFSA Journal 11(1): 3067

European Food Safety Authority (2013b) EFSA guidance document on the risk assessment of plant protection products on bees (Apis mellifera, Bombus spp. and solitary bees). EFSA Journal 11(7): 3295

Everich, R., Schiller, C., Whitehead, J., Beavers, M., Barrett, K. (2009) Effects of Captan on Apis mellifera Brood Development Under Field Conditions in California Almond Orchards. J. Econ. Entomol. 102, 20-29

Forster, R., (2009) Bee poisoning caused by insecticidal seed treatment of maize in Germany in 2008. JuliusKühn-Archiv 423, 126-131

Gallai, N., Salles, J.M., Settele, J., Vaissière, B.E. (2009) Economic valuation of the vulnerability of world agriculture confronted with pollinator decline. Ecol. Econ. $68,810-821$

van der Geest B (2012) Bee poisoning incidents in the Pomurje region of Eastern Slovenia in 2011. JuliusKuhn-Archiv 437, 124

Greatti, M., Sabatini, A.G., Barbattini, R., Rossi, S., Stravisi, A. (2003) Risk of environmental contamination by the active ingredient imidacloprid used for corn seed dressing. Preliminary results. Bull. Insectol. 56, 69-72

Greatti, M., Barbattini, R., Stravisi, A., Sabatini, A.G., Rossi, S. (2006) Presence of the a.i. imidacloprid on vegetation near corn fields sown with gaucho® dressed seeds. Bull. Insectol. 59, 99-103

Gregorc, A., Ellis, J.D. (2011) Cell death localization in situ in laboratory reared honey bee (Apis mellifera L.) larvae treated with pesticides. Pest. Biochem. Physiol. 99, 200-207

Hammer, Ø., Harper, D.A.T., Ryan, P.D. (2001) PAST: Paleontological Statistics Software Package for Education and Data Analysis. Palaeontol. Electron. 4 (1), 9pp

Hendriksma, H.P., Härtel, S., Steffan-Dewenter, I. (2011) Honey bee risk assessment: new approaches for in vitro larvae rearing and data analyses. Methods Ecol. Evol., 2, 509-517

Holm, S., (1979) A Simple Sequentially Rejective Multiple Test Procedure. Scand. J. Stat. 6, 65-70

Janke, M., Rosenkranz, P. (2009) Periodical honey bee colony losses in Germany: preliminary results from a four years monitoring project. Julius-Kühn-Archiv 423, 108-117

Kleinbaum, D.G., Klein, M. 2005 Survival analysis: a selflearning text. Springer

Krupke, C.H., Hunt, G.J., Eitzer, B.D., Andino, G., Given, K. (2012) Multiple Routes of Pesticide Exposure for Honey Bees Living Near Agricultural Fields. PLoS ONE 7(1), e29268

Ladas, A. (1972) Der Einfluss verschiedener Konstitutionsund Umweltfaktoren auf die Anfälligkeit der Honigbiene (Apis mellifica L.) gegenüber zwei insektiziden Pflanzenschutzmitteln. Apidologie, 3, 55-78

Laurino, D., Manino, A., Patetta, A., Porporato, M. (2013) Toxicity of neonicotinoid insecticides on different honey bee genotypes. Bull. Insectol. 66, 119-126

Lu, C., Warchol, K.M., Callahan, R.A. (2012) In situ replication of honey bee colony collapse disorder. Bull. Insectol. 65, 99-106

Maini, S., Medrzycki, P., Porrini, C. (2010) The puzzle of honey bee losses: a brief review. Bull. Insectol. 63, 153-160

Mansour, S.A., Al-Jalil, M.K. (1985) Pesticides and beneficial organisms: 1 . - the response of two honey bee races to certain insecticides. Pesticides 19(3), 39-40

Meixner, M.D., Pinto, M.A., Bouga, M., Kryger, P., Ivanova, E., Fuchs S. (2013) Standard methods for characterising subspecies and ecotypes of Apis mellifera. J. Apic. Res. 52(4), 1-28, DOI: 10.3896 /IBRA.1.52.4.05

Milani, N. (1995) The resistance of Varroa jacobsoni oud to pyrethroids: A laboratory assay. Apidologie 26, 415-429

Mussen, E.C., Lopez, J.E., Peng, C.Y.S (2004) Effects of selected fungicides on growth and development of larval honey bees, Apis mellifera L. (Hymenoptera: Apidae). Environ. Entomol. 33, 1151-1154

Nazzi, F., Brown, S.P., Annoscia, D., Del Piccolo, F., Di Prisco, G., Varricchio, P., Della Vedova, G., Cattonaro, F., Caprio, E., Pennacchio, F. (2012) Synergistic Parasite-Pathogen Interactions Mediated by Host Immunity Can Drive the Collapse of Honeybee Colonies. PLoS Pathog 8(6), e1002735

Neumann, P., Carreck, N.L. (2010) Honey bee colony losses. J. Apic. Res. 49, 1-6 
Nieto, A., Roberts, S.P.M., Kemp, J., Rasmont, P., Kuhlmann, M. et al. (2014) European Red List of bees. Publication Office of the European Union, Luxembourg

Oomen, PA, de Ruijter, A., van der Steen J. (1992) Method for honeybee brood feeding tests with insect growthregulating insecticides. Bull. OEPP/EPPO Bull. 22, 613-616

Pistorius, J., Bischoff, G., Heimbach, U., Stähler, M. (2009) Bee poisoning incidents in Germany in spring 2008 caused by abrasion of active substance from treated seeds during sowing of maize. Julius-Kühn-Archiv 423, 118-126

Potts, S.G., Biesmeijer, J.C., Kremen, C., Neumann, P., Schweiger, O., Kunin, W.E. (2010) Global pollinator declines: trends, impacts and drivers. Trends Ecol. Evol. 25, 345-353

Ratnieks, F.L.W., Carreck, N.L. (2010) Clarity on honey bee collapse? Science 327, 152-153

Robertson, J.L., Preisler, H.K. (1992) Pesticide bioassays with Arthropods. CRC Press, Boca Raton

Rortais, A., Arnold, G., Halm, M.P., Touffet-Briens, F. (2005) Modes of honeybees exposure to systemic insecticides: estimated amounts of contaminated pollen and nectar consumed by different categories of bees. Apidologie 36, 71-83

Schur, A., Tornier, I., Brasse, D., Mühlen, W., von der Ohe, W., Wallner, K., Wehling, M. (2003) Honey bee brood ring-test in 2002: method fort the assessment of side effects of plant protection products on the honey bee brood under semi-field conditions. Bull. Insectol. 56, 91-96
Shimanuki, H., Knox, D.A. (2000) Diagnosis of Honey Bee Diseases. U.S. Department of Agriculture, Agriculture Handbook No. AH- 690

Simon-Delso, N., San Martin, G., Bruneau, E., Minsart, L.A., Mouret, C., Hautier, L. (2014) Honeybee Colony disorder in crop areas: The role of pesticides and viruses. PLoS ONE 9(7), e103073

van der Sluijs, J.P. , Simon-Delso, N., Goulson, D., Maxim, L., Bonmatin, J.-M., Belzunces, L.P. (2013) Neonicotinoids, bee disorders and the sustainability of pollinator services. Curr. Opin. Environ. Sust. 5, 293-305

Suchail, S., Guez, D., Bbelzunces, L.P. (2000) Characteristics of imidacloprid toxicity in two Apis mellifera subspecies. Environ, Toxicol. Chem. 19, 1901-1905

Tavares, D.A., Roat, T.C., Carvalho, S.M., Silva-Zacarin, E.C.M., Osmar Malaspina, O. (2015) In vitro effects of thiamethoxam on larvae of Africanized honey bee Apis mellifera (Hymenoptera: Apidae). Chemosphere $135,370-378$

vanEngelsdorp, D., Evans, J.D., Saegerman, C., Mullin, C., Haubruge, E. et al. (2009) Colony collapse disorder: a descriptive study. PLoS ONE 4, e6481

Williams, G.R., Tarpy, D.R., vanEngelsdorp, D., Chauzat, M.-P., Cox-Foster, D.L., Delaplane, K. S., Neumann, P., Pettis, J.S., Rogers, R.E.L., Shutler, D. (2010) Colony Collapse Disorder in context. Bioessays 32, 845-846

Wu, J.Y., Anelli, C.M., Sheppard, W.S. (2011) Sub-Lethal Effects of Pesticide Residues in Brood Comb on Worker Honey Bee (Apis mellifera) Development and Longevity. PLoS ONE 6(2), e14720 